\section{Effects of Aminoethoxyvinylglycine, Ethephon, and 1-Methylcyclopropene on Apple Fruit Quality at Harvest and after Storage}

\author{
S.R. Drake ${ }^{1}$, D.C. Elfving ${ }^{2}$, M.A. Drake ${ }^{3}$, T.A. Eisele ${ }^{4}$, \\ S.L. Drake ${ }^{5}$, and D.B. Visser ${ }^{6}$
}

AdDitional Index words. Malus $\times$ domestica, 'Scarletspur Delicious', 'Gale Gala', bioregulator, growth regulator, ReTain, Ethrel, SmartFresh, regular storage, air storage, controlled-atmosphere storage

Summary. This study was conducted over two crop seasons using 'Scarletspur Delicious' and 'Gale Gala' apple trees (Malus $\times$ domestica). The bioregulators aminoethoxyvinylglycine (AVG), ethephon (ETH), and 1-methylcyclopropene (MCP) were applied at various times before or after harvest. Fruit response was evaluated at harvest and after regular atmosphere (RA) and controlled atmosphere (CA) storage [2.0\% oxygen $\left(\mathrm{O}_{2}\right)$ and $<2.0 \%$ carbon dioxide $\left(\mathrm{CO}_{2}\right)$ at 0 ${ }^{\circ} \mathrm{C}$ ] and quality of whole and juice apple products evaluated. AVG reduced starch loss and ethylene production, enhanced firmness, and reduced cracking in 'Gale Gala,' but reduced sensory acceptance of apples and apple juice. ETH intensified starch loss, ethylene production, and reduced firmness, but did not affect 'Gale Gala' fruit cracking. AVG followed by ETH reduced starch loss, ethylene production, and cracking and maintained firmness. This combination also aided in sensory acceptance of apples but reduced sensory preference of apple juice. Exposure to postharvest MCP improved flesh firmness retention and reduced ethylene production after both RA and CA storage. MCP either favored or reduced sensory acceptance of whole apples, depending on the particular season, but reduced sensory preference of apple juice. Sensory scores for 'Scarletspur Delicious' apples were more strongly modified by bioregulators than were 'Gale Gala' apples.

$\mathrm{B}$ ioregulator products have been used for many purposes in apple production, including control and manipulation of vegetative growth and regulation of flowering (Elfving and Cline, 1990; Elfving et al., 2003), preharvest drop (Greene et al., 2000), fruit maturity (Byers, 1997; Greene, 2002; Layne et al., 2002; Stover et al., 2003), fruit size, shape, color, firmness, and postharvest quality (Andrews, 2001; Beaudry and Jayanty, 2003; Drake et al., 2002,

The authors wish to express appreciation to the Washington State Tree Fruit Research Commission for grant funds partially supporting this study.

${ }^{1}$ Research Horticulturist, USDA/ARS-TFRL, 1104 N. Western Ave., Wenatchee, WA. 98801.

${ }^{2}$ Professor and Horticulturist, Washington State University, Tree Fruit Research and Extension Center, 1100 N. Western Ave., Wenatchee, WA 98801.

${ }^{3}$ Associate Food Scientist, Department of Food Science, North Carolina State University, Raleigh, NC 27695.

${ }^{4}$ Senior Chemist, Tree Top, Inc., POB 248, Selah, WA 98942.

${ }^{5}$ Research Associate, Department of Food Science, North Carolina State University, Raleigh, NC 27695

${ }^{6}$ Agricultural Research Technologist III, Washington State University, Tree Fruit Research and Extension Center, 1100 N. Western Ave., Wenatchee, WA 98801
2003, 2005a, 2005b; Larrigaudiere et al., 1996; Wang and Dilley, 2001; Williams, 1980). The bioregulators AVG and ETH have been used to inhibit (AVG) or accelerate (ETH) apple fruit ripening and affect other fruit characteristics. AVG acts by inhibiting ethylene biosynthesis in the apple fruit, while ETH produces ethylene in apple tissues upon application, thereby stimulating the onset of ripening when applied just before harvest. A new bioregulator, MCP, interferes with the physiological action of ethylene in apple fruit and is now used to control fruit quality, delay ethylene production, reduce respiration rate, reduce volatile production, inhibit scald development, and slow loss of firmness and acidity (Beaudry and Jayanty, 2003;
Blankenship and Dole, 2003; DeEll et al., 2002; Delong et al., 2004; Drake et al., 2004; Fan and Mattheis, 1999; Fan et al., 1999a, 1999b; Lurie et al., 2002; Mattheis et al., 2001; Watkins et al., 2000). These three bioregulator products provide possible methods for controlling the processes of fruit maturation and ripening, both prior to harvest and during and after storage, especially if used in combination. However, very little is known about the effects of these bioregulators, particularly when applied in combinations, on apple fruit and juice quality. In earlier trials with 'Scarletspur Delicious', ETH alone increased soluble solids content (SSC) and reduced titratable acidity (TA); AVG reduced SSC while not affecting TA (Drake et al., 2005b). When both treatments were applied to the same trees, each treatment tended to counteract the effects of the other. In a companion study, AVG retarded starch loss, ethylene production, red skin color formation, and the development of watercore while maintaining fruit flesh firmness, but reduced sensory scores for whole apples and apple juice (Drake et al., 2005a). In contrast, ETH increased starch loss, red skin color development, and SSC while reducing TA, thus increasing the SSC:TA ratio. ETH did not affect preference scores for whole apples but enhanced sensory preference for treated apple juice.

The key factor for increasing the purchase of apples is said to be taste (Washington Apple Commission, 2002). Therefore, the objective of these studies was to further examine the influence of the bioregulators AVG and ETH and include an evaluation of the new bioregulator MCP when applied either alone or in various combinations on objective and sensory parameters of apple fruit and juice quality at harvest and after storage.

\section{Materials and methods}

This study was conducted over two crop seasons using 'Scarletspur Delicious' /'Malling Merton 111' (MM.111) and 'Gale Gala' /

\begin{tabular}{llll}
\hline $\begin{array}{l}\text { Units } \\
\text { To convert U.S. to SI, } \\
\text { multiply by }\end{array}$ & U.S. unit & SI unit & $\begin{array}{l}\text { To convert SI to U.S., } \\
\text { multiply by }\end{array}$ \\
\hline 0.3048 & $\mathrm{ft}$ & $\mathrm{m}$ & 3.2808 \\
25.4000 & inch $(\mathrm{es})$ & $\mathrm{mm}$ & 0.0394 \\
4.4482 & $\mathrm{lbf}$ & $\mathrm{N}$ & 0.2248 \\
1 & $\mathrm{ppm}$ & $\mathrm{mg} \cdot \mathrm{L}^{-1}$ & 1 \\
$\left({ }^{\circ} \mathrm{F}-32\right) \div 1.8$ & ${ }^{\circ} \mathrm{F}$ & ${ }^{\circ} \mathrm{C}$ & $\left(1.8 \times{ }^{\circ} \mathrm{C}\right)+32$
\end{tabular}


'Budagovsky 118' (B.118) apple trees. The 'Scarletspur Delicious' trees were located in a commercial orchard located in East Wenatchee, Wash., and were planted in 1979 at a spacing of $10 \times 20$ $\mathrm{ft}$. The 'Gale Gala' trees were located in the same commercial orchard in East Wenatchee and were planted in 1998 as offset double rows at a spacing of $10 \times 4 \times 18 \mathrm{ft}$.

Trial 1, 'Scarletspur DeliCIOUS' (YEAR I, 2002). Applications of AVG were made to two four-tree replicates in seven randomized complete blocks to runoff using a hydraulic hand-gun sprayer on 26 Aug. 2002. Trees were sprayed at 4 weeks before first (commercial) harvest $(4 \mathrm{WBH})$ with $125 \mathrm{mg} \cdot \mathrm{L}^{-1}$ AVG supplemented with $0.05 \% \mathrm{v} / \mathrm{v}$ Sylgard 309 surfactant (Wilbur-Ellis, Fresno, Calif.). One four-tree replicate previously treated with AVG and one previously untreated were individually sprayed to runoff using a hydraulic hand-gun sprayer with ETH $150 \mathrm{mg} \cdot \mathrm{L}^{-1}$ at $2 \mathrm{WBH}$ (9 Sept. 2002). The ETH spray was supplemented with $0.1 \% \mathrm{v} / \mathrm{v}$ Regulaid surfactant (Kalo, Overland Park, Kans.). Control trees were not sprayed with either bioregulator or surfactant. One composite fruit sample was collected from each two-tree replicate in each block on 23 Sept. (commercial harvest) and again on 7 Oct. 2002.

Trial 2, 'Gale Gala' (Year I, 2003). Applications of AVG were made to two six-tree replicates in five randomized complete blocks to runoff using a hydraulic hand-gun sprayer on 28 July 2003. Trees were sprayed at $4 \mathrm{WBH}$ with $125 \mathrm{mg} \cdot \mathrm{L}^{-1}$ AVG supplemented with $0.05 \% \mathrm{v} / \mathrm{v}$ Sylgard 309 surfactant. One six-tree replicate previously treated with AVG and one previously untreated were individually sprayed to runoff using a hydraulic hand-gun sprayer with ETH $125 \mathrm{mg} \cdot \mathrm{L}^{-1}$ at $2 \mathrm{WBH}$ (11 Aug. 2003). ETH sprays were supplemented with $0.1 \% \mathrm{v} / \mathrm{v}$ Regulaid surfactant. Control trees were not sprayed with either bioregulator or surfactant. One composite fruit sample was collected from each six-tree replicate in each block on 25 Aug. (commercial harvest) and again on 8 Sept. 2003.

Trial 3, 'Scarletspur DeliCIOUs' (YeAR II, 2003). Applications of AVG were made to two two-tree replicates in five randomized complete blocks to runoff using a hydraulic hand-gun sprayer on 19 Aug. 2003.
Trees were sprayed at $4 \mathrm{WBH}$ with 125 $\mathrm{mg} \cdot \mathrm{L}^{-1}$ AVG supplemented with $0.05 \%$ v/v Sylgard 309 surfactant. One twotree replicate previously treated with AVG and one previously untreated were individually sprayed to runoff using a hydraulic hand-gun sprayer with ETH $300 \mathrm{mg} \cdot \mathrm{L}^{-1}$ at $2 \mathrm{WBH}$ (2 Sept. 2003). The ETH spray was supplemented with $0.1 \% \mathrm{v} / \mathrm{v}$ Regulaid surfactant. Control trees were not sprayed with either bioregulator or surfactant. One composite fruit sample was collected from each two-tree replicate in each block on 16 Sept. (commercial harvest) and again on 30 Sept. 2003.

Trial 4, 'Gale Gala' (Year II, 2004). Applications of AVG were made to two single-tree replicates in five randomized complete blocks to runoff using a hydraulic hand-gun sprayer on 26 July 2004. Trees were sprayed at $4 \mathrm{WBH}$ with $125 \mathrm{mg} \cdot \mathrm{L}^{-1}$ AVG supplemented with $0.05 \% \mathrm{v} / \mathrm{v}$ Sylgard 309 surfactant. One single-tree replicate previously treated with AVG and one previously untreated were individually sprayed to runoff using a hydraulic hand-gun sprayer with ETH $450 \mathrm{mg} \cdot \mathrm{L}^{-1}$ at $2 \mathrm{WBH}$ (9 Aug. 2004). The ETH spray was supplemented with $0.1 \% \mathrm{v} / \mathrm{v}$ Regulaid surfactant. Control trees were not sprayed with either bioregulator or surfactant. One fruit sample was collected from each single-tree replicate in each block on 23 Aug. (commercial harvest) and again on 7 Sept. 2004.

Apples were harvested on two dates each year of the study corresponding to commercial harvest and commercial harvest +2 weeks (23 Sept. and 7 Oct. 2002, Trial 1; 25 Aug. and 8 Sept. 2003, Trial 2; 16 Sept. and 30 Sept. 2003, Trial 3; 23 Aug. and 7 Sept. 2004, Trial 4). In both years, the first harvest of 'Scarletspur Delicious' apples was conducted during the same week as the "general release date" for that cultivar. At each harvest, 140 apples were picked from each treatment and replication. For each trial, 70 apples were exposed to $1 \mathrm{mg} \cdot \mathrm{L}^{-1}$ of MCP for $8 \mathrm{~h}$ at $20^{\circ} \mathrm{C}$ in a sealed chamber with a circulation fan after harvest $(<12 \mathrm{~h})$ while the other 70 sample fruit were maintained in cold storage. In $<24 \mathrm{~h}$, all fruit were placed in either regular air (RA) storage at $1{ }^{\circ} \mathrm{C}$ for $60 \mathrm{~d}$ or controlled-atmosphere (CA) storage $\left[2.0 \% \mathrm{O}_{2}\right.$ and $<2.0 \% \mathrm{CO}_{2}$ at $\left.0{ }^{\circ} \mathrm{C}\right]$ for $120 \mathrm{~d}$.

Fruit quality (firmness, color, soluble solids content, titratable acidity, starch, and ethylene) was determined on 10 fruit per replication within $6 \mathrm{~h}$ of harvest. Thirty randomly selected apples from the fruit treated with MCP and 30 from the non-MCP-treated fruit for each harvest, treatment, and replication were held in RA storage (<1 month) prior to sensory analysis (10 for juice, 20 for whole apples). Juice sensory analysis was conducted at Tree Top, Inc. (Selah, Wash.). Twenty randomly selected apples from the fruit treated with MCP and 30 from the nonMCP-treated fruit for each treatment and replication at commercial harvest only (Harvest I) were packed and sent by 2 -d express to North Carolina State University (NCSU) for sensory analysis of the whole fruit. After CA storage (120 d), sensory quality was determined again on both juice and whole apples. After both RA and CA storage, fruit quality was determined by using 10 apples from the fruit treated with MCP and 10 from the non-MCPtreated fruit for each treatment and replication at commercial harvest only (Harvest I) evaluated immediately after removal from storage and another two groups of 10 apples for each harvest, treatment, and replication were evaluated after ripening for $7 \mathrm{~d}$ at room temperature.

Firmness was determined at two locations per apple with the Ta-XT2 texture analyzer (Texture Technologies, Scarsdale, N.Y.) equipped with an 11.1-mm probe. SSC and TA were determined from an aliquot of expressed juice from a cross-sectional slice from each of the same 10 fruit. Peel and flesh color were determined with the color spectrophotometer (ColorFlex model 45/0; Hunter Labs, Reston, Va.) using the Hunter $L^{*}, a^{*}, b^{*}$ system and calculated hue $(\mathrm{hE})$ values (Hunter and Harold, 1987). An Abbé-type refractometer calibrated at $20^{\circ} \mathrm{C}$ was used to determine SSC. Titratable acidity was measured with a Radiometer titrator (model TTT85; Radiometer, Copenhagen, Denmark). Acids were titrated to $\mathrm{pH} 8.2$ with $0.1 \mathrm{~N}$ sodium hydroxide $(\mathrm{NaOH})$ and expressed as percent malic acid. Starch index (SI) was determined using a rating scale of 1 to 5 (Washington Apple Maturity Program, 1993). Internal ethylene concentration (IEC) was determined on five fruit for each replication, treatment, and storage period using a gas chromatograph (model 5880A; Hewlett 
Packard, Ramsey, Minn.) using a flame ionization detector and equipped with Porapak Q column (Agilent, Palo Alto, Calif.). Fruit disorders were visually assessed by laboratory personnel and expressed as the percentage of each fruit sample showing the disorder. Analysis of variance was determined using MSTAT-C (Michigan State University, East Lansing) and means were separated, where appropriate, by Tukey's test $(P \leq 0.05)$.

JUICE PREPARATION AND SENSORY ANALYSIs. For each replicate fruit sample at commercial harvest only (Harvest I), 10 apples were washed, surface dried, sliced, and juiced using a Omega Juicer (model 4000; Omega Products, Harrisburg, Pa.) at ambient temperatures. Juice was centrifuged in an IEC Centra-7 (International Equipment Co., Needham Heights, Mass.) at $450 \mathscr{g}_{\mathrm{n}}$ and then filtered through an odor-free coffee filter to remove insoluble solids. Juice from each fruit sample within a treatment was combined and stored at $6^{\circ} \mathrm{C}$ for immediate flavor panel evaluation. Sensory testing was conducted in a laboratory environment on the apple juice by a panel of 25 judges (Tree Top) previously trained in apple juice flavor attributes. Each panelist received two samples, a control and a treatment sample that were color coded. Prior to evaluation, panelists were instructed on the proper method for filling out the ballot. Each evaluation session was limited to two groups of two samples.

The ballot consisted of three parts. Each panelist was asked to pick a preference between two samples after tasting the samples in the prescribed order. In addition, each panelist was asked to rate the intensity of the apple flavor for each sample using a nine-point scale where a " 1 " indicated that the apple flavor was "too weak," a " 5 " indicated that the apple flavor was "just right," and a "9" indicated that the flavor was "too strong"; each panelist also was asked to rate the overall "degree of liking" using a nine-point hedonic scale where a "l" represented "dislike extremely," a " 5 " represented "neither like nor dislike," and "9" represented "like extremely."

WHOLE APPLE PREPARATION AND SENSORY ANALYSIS. Consumers were recruited at the NCSU Sensory Service Center in Raleigh. Consumers evaluated freshly cut and cored apple slices for flavor, texture, and overall acceptance using a nine-point hedonic scale as described above. Apples were presented in a randomized balanced order of presentation on paper plates with three-digit codes. Prior to testing, consumers filled out an informed consent form consistent with NCSU Human Subjects Approval and a brief questionnaire on apple consumption habits.

\section{Results and discussion}

At harvest there was a significant interaction of bioregulators with harvest date on starch and ethylene concentration of both 'Scarletspur Delicious' and 'Gale Gala' apples (Table 1). In 'Scarletspur Delicious' apple starch loss was not inhibited by preharvest AVG at commercial harvest each year, but was significantly reduced when fruit were harvested 2 weeks later. AVG inhibited starch loss in 'Gale Gala' apples on both harvest dates both years. In contrast, ETH accelerated starch loss by the first harvest date in 'Scarletspur Delicious' apples both years, while only the higher concentration of ETH in Year II increased starch loss in 'Gale Gala' fruit. The stimulation of starch loss induced by ETH was almost completely controlled if fruit were pretreated with AVG. By the second harvest date, differences in starch loss due to preharvest bioregulators were more pronounced.

Ethylene concentration each year was unaffected by any treatment on the commercial harvest date for both cultivars (Table 1). By the second harvest date both years for 'Scarletspur Delicious' and for Year I in 'Gale Gala', AVG almost completely stopped any change in ethylene concentration, regardless of whether fruit were treated later with ETH or not. Fruit treated with ETH only showed ethylene concentration levels equivalent to or greater than control fruit. In Year II in 'Gale Gala', AVG pretreatment did not inhibit the ETH-induced increase in ethylene concentration. The inhibition of ethylene concentration by AVG in the presence or absence of ETH likely helps explain the reduced starch loss this treatment also produced in both cultivars at harvest.

'Gale Gala' fruit often crack when left on the tree past the commercial harvest period. AVG pretreatment in Year II inhibited the development of this problem in the presence or absence of ETH. ETH treatment did not increase cracking above the control level.

As in a previous study (Drake et al., 2002), neither AVG nor ETH in-

Table 1. Effects of aminoethoxyvinylglycine (AVG) and/or ethephon (ETH) on starch and internal ethylene content (IEC) of 'Scarletspur Delicious' and 'Gale Gala' apples at harvest.

\begin{tabular}{|c|c|c|c|c|c|c|c|c|c|c|}
\hline \multirow[b]{3}{*}{ Harvest } & \multirow[b]{3}{*}{ Bioregulator } & \multicolumn{4}{|c|}{ Scarletspur Delicious } & \multicolumn{5}{|c|}{ Gale Gala } \\
\hline & & \multicolumn{2}{|c|}{$\begin{array}{c}\text { Starch } \\
(1-5)\end{array}$} & \multicolumn{2}{|c|}{$\begin{array}{c}\text { IEC } \\
{\left[\mathrm{mg} \cdot \mathrm{L}^{-1}(\mathrm{ppm})\right]}\end{array}$} & \multicolumn{2}{|c|}{$\begin{array}{c}\text { Starch } \\
(1-5)\end{array}$} & \multicolumn{2}{|c|}{$\begin{array}{c}\text { IEC } \\
{\left[\mathrm{mg} \cdot \mathrm{L}^{-1}(\mathrm{ppm})\right]}\end{array}$} & \multirow{2}{*}{$\begin{array}{c}\begin{array}{c}\text { Cracks } \\
(\%)\end{array} \\
\text { Year II }\end{array}$} \\
\hline & & Year I & Year II & Year I & Year II & Year I & Year II & Year I & Year II & \\
\hline \multirow[t]{3}{*}{ Commercial } & Control & $1.5 \mathrm{~cd}^{\mathrm{x}}$ & $1.6 \mathrm{e}$ & $<0.1 \mathrm{c}$ & $<0.1 \mathrm{c}$ & $1.4 \mathrm{~b} \mathrm{c}$ & $1.8 \mathrm{e}$ & $0.2 \mathrm{~b}$ & $1.6 \mathrm{~cd}$ & $<1.0 \mathrm{c}$ \\
\hline & $\mathrm{AVG}^{\mathrm{z}}$ & $1.4 \mathrm{~d}$ & $1.5 \mathrm{e}$ & $<0.1 \mathrm{c}$ & $<0.0 \mathrm{c}$ & $1.0 \mathrm{~d}$ & $1.2 \mathrm{f}$ & $0.1 \mathrm{~b}$ & $1.2 \mathrm{~d}$ & $<1.0 \mathrm{c}$ \\
\hline & $\mathrm{ETH}^{\mathrm{y}}$ & $1.7 \mathrm{~b}$ & $2.1 \mathrm{~cd}$ & $0.2 \mathrm{c}$ & $0.9 \mathrm{c}$ & $1.4 \mathrm{bc}$ & $2.1 \mathrm{~d}$ & $0.2 \mathrm{~b}$ & $1.4 \mathrm{~d}$ & $<1.0 \mathrm{c}$ \\
\hline \multirow{3}{*}{$\begin{array}{l}\text { Commercial } \\
+ \\
\text { Two weeks }\end{array}$} & $\mathrm{AVG}^{\mathrm{z}}$ & $1.5 \mathrm{~cd}$ & $1.7 \mathrm{e}$ & $0.2 \mathrm{c}$ & $0.2 \mathrm{c}$ & $1.5 \mathrm{bc}$ & $2.2 \mathrm{~d}$ & $0.2 \mathrm{~b}$ & $1.9 \mathrm{bc}$ & $28.0 \mathrm{~b}$ \\
\hline & $\mathrm{ETH}^{\mathrm{y}}$ & $2.0 \mathrm{a}$ & $3.1 \mathrm{a}$ & $4.8 \mathrm{a}$ & $4.8 \mathrm{a}$ & $2.8 \mathrm{a}$ & $3.6 \mathrm{a}$ & $2.8 \mathrm{a}$ & $2.2 \mathrm{ab}$ & $82.0 \mathrm{a}$ \\
\hline & $\mathrm{AVG}+\mathrm{ETH}$ & $1.8 \mathrm{~b}$ & $2.4 \mathrm{~b}$ & $0.6 \mathrm{c}$ & $0.7 \mathrm{c}$ & $1.7 \mathrm{~b}$ & $2.6 \mathrm{c}$ & $0.4 \mathrm{~b}$ & $2.0 \mathrm{ab}$ & $38.0 \mathrm{~b}$ \\
\hline
\end{tabular}

${ }^{\mathrm{z}} \mathrm{AVG}$ applied 4 weeks before commercial harvest at $125 \mathrm{mg} \cdot \mathrm{L}^{-1}$.

yETH applied 2 weeks before commercial harvest at $150 \mathrm{mg} \cdot \mathrm{L}^{-1}$ in Year I and $300 \mathrm{mg} \cdot \mathrm{L}^{-1}$ in Year II ('Scarletspur Delicious') or at $300 \mathrm{mg} \cdot \mathrm{L}^{-1}$ in $\mathrm{Year} \mathrm{I}$ and $450 \mathrm{mg} \cdot \mathrm{L}^{-1}$ in Year II ('Gale Gala').

${ }^{x}$ Means in a column not followed by a common letter are significantly different $(P \leq 0.05)$. 
fluenced the peel color of 'Scarletspur Delicious' apples in this study (data not shown). This lack of color difference would be expected due to the extremely dark red color produced early in the growing season by this strain. There were some color differences due to AVG and ETH use on 'Gale Gala' apples; red color development was retarded with AVG alone but not enhanced with ETH (data not shown). Color differences between AVG-treated and control apples ranged from 2 to 3 color units (hue) and would be visible to the consumer (Hunter and Harold, 1987).

Flesh firmness values for both 'Scarletspur Delicious' and 'Gale Gala' apples were influenced by the interaction of bioregulator with harvest date (Table 2). In 'Scarletspur Delicious', on the first harvest date in Year I the ETHtreated fruit were somewhat softer than control or AVG-treated fruit, while there were no differences in Year II. In contrast, by the second harvest date in Year I all firmness differences due to treatments had disappeared, while in Year II the AVG-only fruit were firmer than the ETH-only fruit. The heavier ETH dose in Year II may have accounted for the firmness differences noted on the second harvest date. In 'Gale Gala' the AVG-treated fruit were firmer than controls on the first harvest date both years while the AVG + ETH fruit were firmer only in Year II. On the second harvest date both years AVG-treated fruit were firmer than controls and ETH-treated fruit and held firmness in fruit that received a later ETH treatment after AVG. This pattern was more strongly pronounced in Year II, likely reflecting the higher ETH dose used that year.

Regardless of the cultivar, stor-

Table 2. Effects of aminoethoxyvinylglycine (AVG) and/or ethephon (ETH) on flesh firmness of 'Scarletspur Delicious' and 'Gale Gala' apples at harvest.

\begin{tabular}{|c|c|c|c|c|c|}
\hline \multirow[b]{3}{*}{ Harvest } & \multirow[b]{3}{*}{ Bioregulator } & \multicolumn{4}{|c|}{ Firmness $(\mathrm{N})^{\mathrm{z}}$} \\
\hline & & \multicolumn{2}{|c|}{ Scarletspur Delicious } & \multicolumn{2}{|c|}{ Gale Gala } \\
\hline & & Year I & Year II & Year I & Year II \\
\hline \multirow[t]{4}{*}{ Commercial } & Control & $83.2 \mathrm{a}^{\mathrm{w}}$ & 79.8 a & $100.9 \mathrm{~b}$ & $98.9 \mathrm{~b}$ \\
\hline & $\mathrm{AVG}^{\mathrm{y}}$ & $82.6 \mathrm{a}$ & $81.5 \mathrm{a}$ & $103.8 \mathrm{a}$ & $104.2 \mathrm{a}$ \\
\hline & $\mathrm{ETH}^{\mathrm{x}}$ & $80.8 \mathrm{~b}$ & $79.7 \mathrm{a}$ & $98.5 \mathrm{~b}$ & $95.8 \mathrm{~b}$ \\
\hline & $\mathrm{AVG}+\mathrm{ETH}$ & $79.9 \mathrm{~b}$ & $79.6 \mathrm{a}$ & $101.7 \mathrm{ab}$ & $102.5 \mathrm{a}$ \\
\hline \multirow{4}{*}{$\begin{array}{l}\text { Commercial } \\
+ \\
\text { Two weeks }\end{array}$} & Control & $77.9 \mathrm{c}$ & $74.8 \mathrm{bc}$ & $81.7 \mathrm{~d}$ & $83.5 \mathrm{~d}$ \\
\hline & $\mathrm{AVG}^{\mathrm{y}}$ & $78.0 \mathrm{c}$ & $78.4 \mathrm{ab}$ & $92.6 \mathrm{c}$ & $88.6 \mathrm{c}$ \\
\hline & $\mathrm{ETH}^{\mathrm{x}}$ & $76.6 \mathrm{c}$ & $74.1 \mathrm{c}$ & $82.2 \mathrm{~d}$ & $78.9 \mathrm{e}$ \\
\hline & $\mathrm{AVG}+\mathrm{ETH}$ & $77.0 \mathrm{c}$ & $74.7 \mathrm{bc}$ & $88.3 \mathrm{c}$ & $84.1 \mathrm{~d}$ \\
\hline
\end{tabular}

${ }^{2} 1 \mathrm{~N}=0.2248 \mathrm{lbf}$

yAVG applied 4 weeks before commercial harvest at $125 \mathrm{mg} \cdot \mathrm{L}^{-1}(\mathrm{ppm})$.

${ }^{x}$ ETH applied 2 weeks before commercial harvest at $150 \mathrm{mg} \cdot \mathrm{L}^{-1}$ in Year I and $300 \mathrm{mg} \cdot \mathrm{L}^{-1}$ in Year II ('Scarletspur Delicious') or at $300 \mathrm{mg} \cdot \mathrm{L}^{-1}$ in Year I and $450 \mathrm{mg} \cdot \mathrm{L}^{-1}$ in Year II ('Gale Gala').

"Means in a column not followed by a common letter are significantly different $(P \leq 0.05)$. age type, or year, AVG alone or in combination with ETH inhibited ethylene concentration in the absence of postharvest MCP (Table 3). When MCP was used, it tended to dominate the control of ethylene concentration regardless of the preharvest bioregulator program or the storage conditions. In the absence of MCP, ethylene concentration was not enhanced with ETH except for 'Gale Gala' fruit not treated with MCP. When treated with MCP, apples produced very little ethylene $\left(\leq 1.6 \mathrm{mg} \cdot \mathrm{L}^{-1}\right)$.

Without MCP, 'Scarletspur Delicious' apples treated with AVG were firmer than control apples, apples treated with ETH were substantially softer, and the combination of AVG + ETH resulted in intermediate levels of firmness after both RA and CA storage (Table 4). AVG partially counteracted the softening effect of ETH, probably through its control over ethylene concentration. 'Gale Gala' apples not treated with MCP showed a generally similar pattern in which AVG maintained firmness, even when followed by ETH. This firmness advantage for AVG-treated apples was in excess of $5.0 \mathrm{~N}$ for 'Scarletspur Delicious' apples after RA storage and 7.0 $\mathrm{N}$ after CA storage, compared to the firmness of control apples. AVG produced a similar firmness advantage on 'Gale Gala' apples after both storage conditions. When ETH was used alone on 'Scarletspur Delicious' apples, some firmness values were reduced by ETH below grade standards $(<53.3$ $\mathrm{N}$ ), particularly for apples from CA storage (Washington State Legislature,

Table 3. Effects of preharvest aminoethoxyvinylglycine (AVG) and/or ethephon (ETH) with or without postharvest application of 1-methylcyclopropene (MCP) on internal ethylene concentration (IEC) of 'Scarletspur Delicious' and 'Gale Gala' apples after regular (RA) and controlled atmosphere (CA) storage. Data shown for commercial harvest (Harvest I) only.

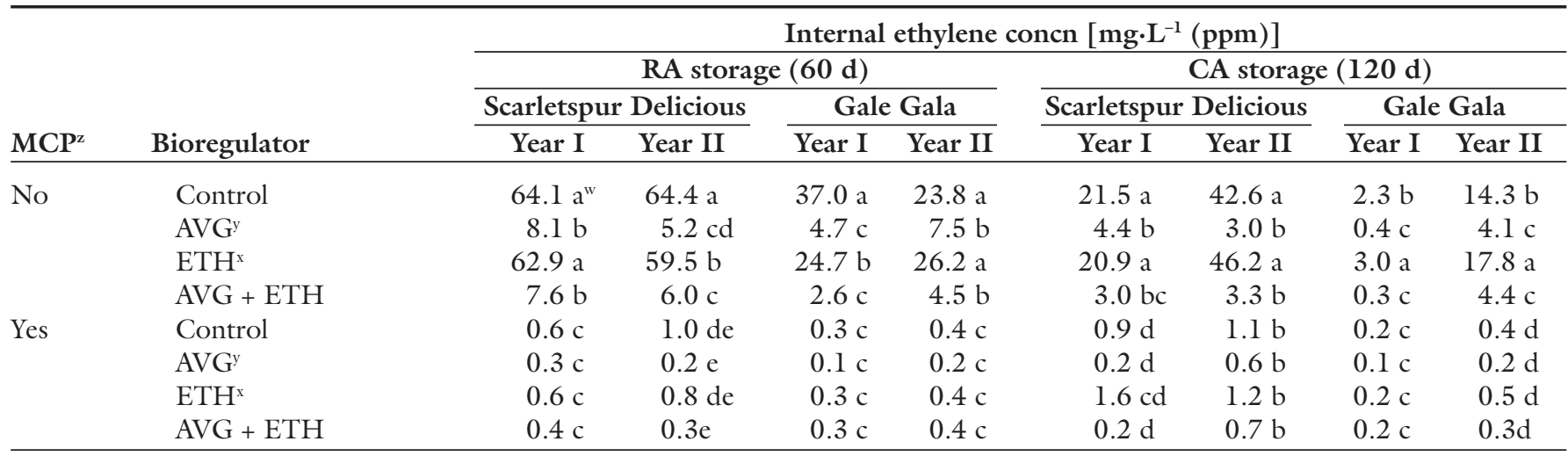

${ }^{\mathrm{z}} \mathrm{MCP}$ applied at $1.0 \mathrm{mg} \cdot \mathrm{L}-\mathrm{l}<12 \mathrm{~h}$ after harvest.

yAVG applied 4 weeks before commercial harvest at $125 \mathrm{mg} \cdot \mathrm{L}^{-1}$

${ }^{x}$ ETH applied 2 weeks before commercial harvest at $150 \mathrm{mg} \cdot \mathrm{L}^{-1}$ in Year I and $300 \mathrm{mg} \cdot \mathrm{L}^{-1}$ in Year II ('Scarletspur Delicious') or at $300 \mathrm{mg} \cdot \mathrm{L}^{-1}$ in $\mathrm{Year} \mathrm{I}$ and $450 \mathrm{mg} \cdot \mathrm{L}^{-1}$ in Year II ('Gale Gala').

weans in a column not followed by a common letter are significantly different $(P \leq 0.05)$ 
Table 4. Effects of preharvest aminoethoxyvinylglycine (AVG) and/or ethephon (ETH) with or without postharvest application of 1-methylcyclopropene (MCP) on flesh firmness (Newtons) of 'Scarletspur Delicious' and 'Gale Gala' apples after regular (RA) and controlled atmosphere (CA) storage. Data shown for commercial harvest (Harvest I) only.

\begin{tabular}{|c|c|c|c|c|c|c|c|c|c|}
\hline \multirow[b]{4}{*}{$\mathrm{MCP}^{\mathrm{z}}$} & \multirow[b]{4}{*}{ Bioregulator } & \multicolumn{8}{|c|}{ Flesh firmness $(\mathrm{N})^{\mathrm{z}}$} \\
\hline & & \multicolumn{4}{|c|}{ RA storage $(60 \mathrm{~d})$} & \multicolumn{4}{|c|}{ CA storage $(120 \mathrm{~d})$} \\
\hline & & \multicolumn{2}{|c|}{ Scarletspur Delicious } & \multicolumn{2}{|c|}{ Gale Gala } & \multicolumn{2}{|c|}{ Scarletspur Delicious } & \multicolumn{2}{|c|}{ Gale Gala } \\
\hline & & Year I & Year II & Year I & Year II & Year I & Year II & Year I & Year II \\
\hline \multirow[t]{4}{*}{ No } & Control & $56.9 \mathrm{~d}^{\mathrm{v}}$ & $60.5 \mathrm{~d}$ & $62.1 \mathrm{~d}$ & $65.4 \mathrm{e}$ & $58.6 \mathrm{f}$ & $58.3 \mathrm{e}$ & $76.5 \mathrm{~d}$ & $67.4 \mathrm{e}$ \\
\hline & $\mathrm{AVG}^{\mathrm{x}}$ & $63.5 \mathrm{~b}$ & $65.2 \mathrm{c}$ & $66.1 \mathrm{c}$ & $69.9 \mathrm{~d}$ & $65.8 \mathrm{~d}$ & $69.1 \mathrm{c}$ & $83.9 \mathrm{c}$ & $72.5 \mathrm{~d}$ \\
\hline & $\mathrm{ETH}^{\mathrm{w}}$ & $55.3 \mathrm{e}$ & $55.0 \mathrm{f}$ & $60.7 \mathrm{~d}$ & $63.6 \mathrm{f}$ & $56.4 \mathrm{~g}$ & $52.5 \mathrm{f}$ & $75.9 \mathrm{~d}$ & $65.5 \mathrm{f}$ \\
\hline & $\mathrm{AVG}+\mathrm{ETH}$ & $60.4 \mathrm{c}$ & $58.9 \mathrm{e}$ & $66.2 \mathrm{c}$ & $69.3 \mathrm{~d}$ & $64.5 \mathrm{e}$ & $60.2 \mathrm{~d}$ & $82.9 c$ & $71.6 \mathrm{~d}$ \\
\hline \multirow[t]{4}{*}{ Yes } & Control & $76.8 \mathrm{a}$ & $71.2 \mathrm{~b}$ & $81.6 \mathrm{~b}$ & $79.2 \mathrm{c}$ & $71.9 \mathrm{~b}$ & $71.4 \mathrm{~b}$ & $84.3 \mathrm{c}$ & $80.0 \mathrm{~b}$ \\
\hline & $\mathrm{AVG}^{\mathrm{x}}$ & $76.8 \mathrm{a}$ & $73.3 \mathrm{a}$ & $89.4 \mathrm{a}$ & $86.0 \mathrm{a}$ & $73.1 \mathrm{a}$ & $72.9 \mathrm{a}$ & $90.1 \mathrm{a}$ & $84.7 \mathrm{a}$ \\
\hline & $\mathrm{ETH}^{\mathrm{w}}$ & $78.0 \mathrm{a}$ & $70.9 \mathrm{~b}$ & $82.7 \mathrm{~b}$ & $78.8 \mathrm{c}$ & $70.2 c$ & $72.0 \mathrm{ab}$ & $83.3 \mathrm{c}$ & $77.4 \mathrm{c}$ \\
\hline & $\mathrm{AVG}+\mathrm{ETH}$ & $77.1 \mathrm{a}$ & $72.6 \mathrm{a}$ & $87.3 \mathrm{a}$ & $83.3 \mathrm{~b}$ & $73.6 \mathrm{a}$ & $72.0 \mathrm{ab}$ & $86.9 \mathrm{~b}$ & $83.2 \mathrm{a}$ \\
\hline
\end{tabular}

$\mathrm{N}=0.2248 \mathrm{lbf}$

${ }^{y} \mathrm{MCP}$ applied at $1.0 \mathrm{mg} \cdot \mathrm{L}^{-1}(\mathrm{ppm})<12 \mathrm{~h}$ after harvest.

${ }^{x}$ AVG applied 4 weeks before commercial harvest at $125 \mathrm{mg} \cdot \mathrm{L}^{-1}$.

"ETH applied 2 weeks before commercial harvest at $150 \mathrm{mg} \cdot \mathrm{L}^{-1}$ in Year I and $300 \mathrm{mg} \cdot \mathrm{L}^{-1}$ in Year II ('Scarletspur Delicious') or at $300 \mathrm{mg} \cdot \mathrm{L}^{-1}$ in $\mathrm{Year} \mathrm{I}$ and $450 \mathrm{mg} \cdot \mathrm{L}^{-1}$ in Year II ('Gale Gala').

"Means in a column not followed by a common letter are significantly different $(P \leq 0.05)$.

1990). Applying both AVG and ETH produced firmness values in excess of control apples or apples treated with ETH alone. In all instances, apples treated with AVG + ETH exceeded Washington State grade standards for firmness.

Inclusion of postharvest MCP resulted in very firm apples $(>72.0$ $\mathrm{N})$ regardless of preharvest treatment with either AVG, ETH, or AVG + ETH, and storage condition. Firmness values were high, particularly for apples treated with AVG, or AVG + ETH combined with MCP compared to MCP-treated control apples. Apples treated with ETH followed by MCP tended to have firmness values that were lower than for apples treated with AVG or MCP, but were still very firm. Differences in firmness values for apples treated with MCP and either AVG or ETH tended to be consistent, except for 'Scarletspur Delicious' apples in the Year I, when no differences in firmness were present. In all instances, apples treated with MCP displayed firmness values that exceeded grade standards.

Postharvest application of MCP did not influence the SSC of 'Scarletspur Delicious' apples, but maintained TA and thereby reduced SSC:TA ratio of this cultivar after both RA and CA storage (Table 5). Postharvest application of MCP on 'Gale Gala' apples usually resulted in increased SSC but always resulted in greater TA and reduced SSC:TA ratio. The changes in TA of 'Scarletspur Delicious' and

Table 5. Effects of postharvest 1-methylcyclopropene (MCP) on soluble solids content (SSC), titratable acidity (TA) and their ratio (SSC:TA) of 'Scarletspur Delicious' and 'Gale Gala' apples after regular (RA) and controlled atmosphere (CA) storage. Data shown for commercial harvest (Harvest I) only.

\begin{tabular}{|c|c|c|c|c|c|c|c|}
\hline \multirow[b]{2}{*}{ Storage } & \multirow[b]{2}{*}{$\mathrm{MCP}^{\mathrm{z}}$} & \multicolumn{2}{|c|}{$\begin{array}{l}\text { Soluble solids } \\
\text { content }(\%)\end{array}$} & \multicolumn{2}{|c|}{$\begin{array}{c}\text { Titratable acidity } \\
(\% \text { malic acid })\end{array}$} & \multicolumn{2}{|c|}{$\begin{array}{c}\text { SSC:TA } \\
\text { (ratio) }\end{array}$} \\
\hline & & Year $\mathbf{I}^{\mathbf{y}}$ & Year II & Year I & Year II & Year I & Year II \\
\hline \multicolumn{8}{|c|}{ Scarletspur Delicious } \\
\hline \multirow[t]{2}{*}{$60 \mathrm{~d}$ (RA) } & No & $13.7 a^{x}$ & $13.8 \mathrm{a}$ & $0.23 \mathrm{~b}$ & $0.24 \mathrm{~b}$ & $60.2 \mathrm{a}$ & $57.8 \mathrm{a}$ \\
\hline & Yes & $13.7 \mathrm{a}$ & $13.8 \mathrm{a}$ & $0.25 \mathrm{a}$ & $0.26 \mathrm{a}$ & $55.0 \mathrm{~b}$ & $53.6 \mathrm{~b}$ \\
\hline \multirow[t]{3}{*}{$120 \mathrm{~d}(\mathrm{CA})$} & No & $14.2 \mathrm{a}$ & $14.2 \mathrm{a}$ & $0.22 \mathrm{~b}$ & $0.24 \mathrm{~b}$ & $64.2 \mathrm{a}$ & $60.9 \mathrm{a}$ \\
\hline & Yes & $14.3 \mathrm{a}$ & $14.1 \mathrm{a}$ & $0.23 \mathrm{a}$ & $0.25 \mathrm{a}$ & $61.1 \mathrm{~b}$ & $57.6 \mathrm{~b}$ \\
\hline & \multicolumn{7}{|c|}{ Gale Gala } \\
\hline \multirow[t]{2}{*}{$60 \mathrm{~d}(\mathrm{RA})$} & No & $13.0 \mathrm{~b}$ & $14.5 \mathrm{~b}$ & $0.35 \mathrm{~b}$ & $0.33 \mathrm{~b}$ & $37.9 \mathrm{a}$ & $44.7 \mathrm{a}$ \\
\hline & Yes & $13.2 \mathrm{a}$ & $14.6 \mathrm{a}$ & $0.42 \mathrm{a}$ & $0.41 \mathrm{a}$ & $31.5 \mathrm{~b}$ & $35.5 \mathrm{~b}$ \\
\hline \multirow[t]{2}{*}{$120 \mathrm{~d}(\mathrm{CA})$} & No & $13.4 \mathrm{a}$ & $14.6 \mathrm{~b}$ & $0.38 \mathrm{~b}$ & $0.33 \mathrm{~b}$ & $35.7 \mathrm{a}$ & $43.9 \mathrm{a}$ \\
\hline & Yes & $13.4 \mathrm{a}$ & $14.7 \mathrm{a}$ & $0.41 \mathrm{a}$ & $0.40 \mathrm{a}$ & $33.1 \mathrm{~b}$ & $32.1 \mathrm{~b}$ \\
\hline
\end{tabular}

${ }^{2} \mathrm{MCP}$ applied at $1.0 \mathrm{mg} \cdot \mathrm{L}^{-1}(\mathrm{ppm})<12 \mathrm{~h}$ after harvest.

y'Scarletspur Delicious' Year I (2002), Year II (2003); 'Gale Gala' Year I (2003), Year II (2004).

${ }^{x}$ Means in a column within cultivars and storage terms not followed by a common letter are significantly different $(P \leq 0.05)$.

SSC of 'Gale Gala' apples, although significant, were minimal at best and it is doubtful these changes would be noticed by a consumer. The changes in TA of 'Gale Gala' apples as a result of MCP were very evident after both RA and CA storage and would be of a magnitude to influence flavor. MCP consistently resulted in reduced SSC: TA ratio regardless of cultivar or storage condition. Differences in the SSC:TA ratio of 'Scarletspur Delicious' apples after RA storage were greater $(4.2+)$ than after CAstorage $(3 \cdot 1+)$. This same pattern was present in the SSC:TA ratio of 'Gale Gala' apples. Consumers typically prefer apples with higher
SSC, TA, or SSC:TA ratios (Boylston et al., 1994) or apple juice with a SSC: TA ratio between 30 and 40 (Jordan et al., 2001). In this study, use of MCP reduced the SS:TA ratio in both 'Scarletspur Delicious' and 'Gale Gala' apples after both RA and CA storage, but the effect of this specific change on consumer preference is unclear.

Bioregulators had a strong influence on the sensory qualities of 'Scarletspur Delicious' apples at harvest and after CA storage (Table 6). At harvest in Year I, apples treated with either ETH or ETH + AVG were superior in "overall" acceptance scores to either control apples or apples treated 
with AVG alone. When apple flavor was considered, only apples treated with ETH were superior to control apples or to apples treated with AVG. Treating apples with AVG tended to reduce flavor scores, but the treatment of AVG-treated fruit with ETH tended to offset the AVG-induced reduction in flavor scores. Texture scores were similar among bioregulators except for apples treated with ETH + AVG, which displayed superior texture scores when compared to apples treated with the other bioregulators. At harvest in Year II, there were no differences in "overall" acceptance or flavor of apples treated with bioregulators, but apples treated with ETH or ETH + AVG were rated superior in texture. This difference in sensory scores between years can possibly be attributed to the fact that during Year II apples were slightly more mature when evaluated and this could attenuate differences early in the season.

After CA storage, AVG-treated apples were scored lower in "overall" acceptance and flavor compared to control apples during Year I (Table 6). In Year II, "overall" acceptance scores for AVG-treated apples were superior to control apples while flavor scores were similar. AVG-treated apples were superior in texture compared to control apples regardless of the year in question. ETH-treated apples were similar to control apples for "overall" acceptance and flavor in both years. Texture scores for ETH-treated apples were lowest in Year I and superior in Year II compared to the scores for control apples. Reduced apple texture as a response to ETH application has been reported on other occasions (Drake et al., 2002; Stover et al., 2003; Wang and Dilley, 2001), but these differences were objective and not subjective. In this study sensory texture scores compare with objective texture scores as shown in Table 4.

MCP-treated apples were equivalent to control apples in "overall" acceptance and were superior in sensory texture, but flavor scores for MCP-treated apples were lower in Year I (Table 6). In Year II, MCP-treated apples were superior to control apples in "overall" acceptance, flavor, and texture. Lawless and Heymann (1999) determined that texture can play a crucial role in overall acceptability and there is some indication that superior texture can mask reduced flavor. In our study

Table 6. Effects of preharvest aminoethoxyvinylglycine (AVG) and/or ethephon (ETH) with or without postharvest application of 1-methylcyclopropene (MCP) on sensory evaluation of 'Scarletspur Delicious' apples at harvest and after controlled atmosphere (CA) storage.

\begin{tabular}{|c|c|c|c|c|c|c|}
\hline \multirow[b]{2}{*}{ Bioregulator } & \multicolumn{3}{|c|}{ Year I } & \multicolumn{3}{|c|}{ Year II } \\
\hline & $\begin{array}{c}\text { Overallz }^{z} \\
(1-9)\end{array}$ & $\begin{array}{c}\text { Flavor }^{\mathrm{z}} \\
(1-9)\end{array}$ & $\begin{array}{c}\text { Texture }^{\mathrm{z}} \\
(1-9)\end{array}$ & $\begin{array}{c}\text { Overall }^{\mathrm{z}} \\
(1-9)\end{array}$ & $\begin{array}{c}\text { Flavor }^{\mathrm{z}} \\
(1-9)\end{array}$ & $\begin{array}{c}\text { Texture }^{\mathrm{z}} \\
(1-9)\end{array}$ \\
\hline \multicolumn{7}{|c|}{ Commercial harvest } \\
\hline Control & $6.2 \mathrm{~b}^{\mathrm{v}}$ & $6.2 \mathrm{bc}$ & $6.5 \mathrm{~b}$ & $6.5 \mathrm{a}$ & $6.5 \mathrm{a}$ & $6.6 \mathrm{~b}$ \\
\hline $\mathrm{AVG}^{\mathrm{y}}$ & $6.0 \mathrm{~b}$ & $5.9 \mathrm{c}$ & $6.4 \mathrm{~b}$ & $6.5 \mathrm{a}$ & $6.4 \mathrm{a}$ & $6.6 \mathrm{~b}$ \\
\hline $\mathrm{ETH}^{\mathrm{x}}$ & $6.5 \mathrm{a}$ & $6.5 \mathrm{a}$ & $6.5 \mathrm{~b}$ & $6.6 \mathrm{a}$ & $6.5 \mathrm{a}$ & $6.9 \mathrm{a}$ \\
\hline $\mathrm{AVG}+\mathrm{ETH}$ & $6.5 \mathrm{a}$ & $6.4 \mathrm{ab}$ & $6.8 \mathrm{a}$ & $6.5 \mathrm{a}$ & $6.2 \mathrm{a}$ & $6.9 \mathrm{a}$ \\
\hline \multicolumn{7}{|c|}{ After 120 d CA storage } \\
\hline Control & $6.5 \mathrm{ab}$ & $6.5 \mathrm{a}$ & $6.3 \mathrm{~b}$ & $6.1 \mathrm{~b}$ & $6.2 \mathrm{~b}$ & $5.9 \mathrm{c}$ \\
\hline $\mathrm{AVG}^{\mathrm{y}}$ & $5.8 \mathrm{c}$ & $6.0 \mathrm{~b}$ & $6.9 \mathrm{a}$ & $6.6 \mathrm{a}$ & $6.4 \mathrm{ab}$ & $7.2 \mathrm{ab}$ \\
\hline ETH $^{x}$ & $6.7 \mathrm{a}$ & $6.6 \mathrm{a}$ & $5.6 \mathrm{c}$ & $6.6 \mathrm{a}$ & $6.2 \mathrm{~b}$ & $6.9 \mathrm{~b}$ \\
\hline $\mathrm{MCP}^{\mathrm{w}}$ & $6.3 \mathrm{~b}$ & $6.0 \mathrm{~b}$ & $6.8 \mathrm{a}$ & $6.7 \mathrm{a}$ & $6.7 \mathrm{a}$ & $7.3 \mathrm{a}$ \\
\hline
\end{tabular}

${ }^{2}$ Evaluated on a nine-point hedonic scale.

yAVG applied 4 weeks before commercial harvest at $125 \mathrm{mg} \cdot \mathrm{L}^{-1}$ (ppm).

${ }^{x}$ ETH applied 2 weeks before commercial harvest at $150 \mathrm{mg} \cdot \mathrm{L}^{-1}$ in Year I and $300 \mathrm{mg} \cdot \mathrm{L}^{-1}$ in Year II.

${ }^{\text {w } M C P}$ applied at $1.0 \mathrm{mg} \cdot \mathrm{L}^{-1}<12 \mathrm{~h}$ after harvest. All combination preharvest/postharvest MCP treatments not run.

${ }^{\mathrm{V}}$ Means in a column at harvest or after storage not followed by a common letter are significantly different $(P \leq$ $0.05)$.

Table 7. Effects of preharvest aminoethoxyvinylglycine (AVG) and/or ethephon (ETH) with or without postharvest application of 1-methylcyclopropene (MCP) on sensory evaluation of 'Scarletspur Delicious' apple juice at harvest and after controlled-atmosphere (CA) storage.

\begin{tabular}{|c|c|c|c|c|c|c|}
\hline \multirow[b]{2}{*}{ Bioregulator } & \multicolumn{3}{|c|}{ Year I } & \multicolumn{3}{|c|}{ Year II } \\
\hline & $\begin{array}{c}\text { Preference }^{\mathrm{z}} \\
(\mathrm{C} / \mathrm{T})\end{array}$ & $\begin{array}{c}\text { Intensity }^{y} \\
(1-9)\end{array}$ & $\begin{array}{c}\text { Liking }^{y} \\
(1-9)\end{array}$ & $\begin{array}{c}\text { Preference }^{\mathrm{x}} \\
(\mathrm{C} / \mathrm{T})\end{array}$ & $\begin{array}{c}\text { Intensity }^{\mathrm{y}} \\
(1-9)\end{array}$ & $\begin{array}{c}\text { Liking }^{y} \\
(1-9)\end{array}$ \\
\hline \multicolumn{7}{|c|}{ Commercial harvest } \\
\hline Control & & $4.9 \mathrm{a}^{\mathrm{u}}$ & $7.4 \mathrm{a}$ & & $4.8 \mathrm{a}$ & $7.4 \mathrm{a}$ \\
\hline $\mathrm{AVG}^{\mathrm{x}}$ & $19 / 6^{* *}$ & $4.6 \mathrm{a}$ & $6.6 \mathrm{~b}$ & $20 / 5^{* *}$ & $3.9 \mathrm{~b}$ & $6.1 \mathrm{~b}$ \\
\hline $\mathrm{ETH}^{\mathrm{w}}$ & $16 / 9$ & $4.8 \mathrm{a}$ & $6.5 \mathrm{~b}$ & $12 / 13$ & $5.0 \mathrm{a}$ & $7.1 \mathrm{a}$ \\
\hline $\mathrm{AVG}+\mathrm{ETH}$ & $12 / 12$ & $4.6 \mathrm{a}$ & $7.1 \mathrm{a}$ & $17 / 8^{*}$ & $4.4 \mathrm{a}$ & $6.9 \mathrm{a}$ \\
\hline \multicolumn{7}{|c|}{ After 120 d CA storage } \\
\hline Control & & $4.9 \mathrm{a}$ & $7.3 \mathrm{a}$ & & $4.8 \mathrm{a}$ & $7.4 \mathrm{a}$ \\
\hline $\mathrm{AVG}^{\mathrm{x}}$ & $20 / 5^{* *}$ & $4.3 \mathrm{~b}$ & $6.5 \mathrm{~b}$ & ---- & --- & --- \\
\hline $\mathrm{ETH}^{\mathrm{w}}$ & $15 / 10$ & $4.4 \mathrm{~b}$ & $6.6 \mathrm{~b}$ & $12 / 13$ & $5.0 \mathrm{a}$ & $7.4 \mathrm{a}$ \\
\hline $\mathrm{AVG}+\mathrm{ETH}$ & $17 / 8^{*}$ & $4.2 \mathrm{~b}$ & $7.2 \mathrm{a}$ & --- & --- & --- \\
\hline $\mathrm{MCP}^{\mathrm{v}}$ & $15 / 10$ & $4.3 \mathrm{~b}$ & $7.3 \mathrm{a}$ & $18 / 7^{*}$ & $4.0 \mathrm{~b}$ & $6.5 \mathrm{~b}$ \\
\hline
\end{tabular}

${ }^{2}$ Number of panelists with preference for control (C) over treatment (T).

${ }^{y}$ Evaluated on a nine-point hedonic scale.

${ }^{x}$ AVG applied 4 weeks before commercial harvest at $125 \mathrm{mg} \cdot \mathrm{L}^{-1}(\mathrm{ppm})$.

wETH applied 2 weeks before commercial harvest at $150 \mathrm{mg} \cdot \mathrm{L}^{-1}$ in Year I and $300 \mathrm{mg} \cdot \mathrm{L}^{-1}$ in Year II.

${ }^{v} \mathrm{MCP}$ applied at $1.0 \mathrm{mg} \cdot \mathrm{L}^{-1}<12 \mathrm{~h}$ after harvest. All combination preharvest/postharvest MCP treatments not run.

"Means in a column at harvest or after storage not followed by a common letter are significantly different $(P \leq$ $0.05),{ }^{*}{ }^{* *}(P \leq 0.05,0.01)$.

there were very significant, convincing differences in texture scores for MCPtreated apples compared to control apples, particularly during the second evaluation. No differences in sensory scores were noted when AVG-treated apples were compared to MCP-treated apples, except for "overall” acceptance in one instance.

Sensory scores for 'Scarletspur Delicious' apple juice were also influenced by bioregulators, and the differences were more consistent than sensory scores for whole apples (Table 7). At harvest and after CA storage, panelists preferred juice from control apples compared to juice from apples treated with AVG. Intensity scores were unaffected by treatment at harvest in Year I but lower for AVG-treated fruit in Year II, whereas liking scores for AVG-treated fruit were lower both years. No differences in "preference," "intensity," or "liking" were evident 
for juice from ETH-treated apples when compared to juice from control apples at harvest.

After CA storage, control fruit showed the highest intensity score in Year I and were scored as high as ETH-treated fruit in Year II. Juice scores from ETH-treated apples were similar compared to juice from control apples except for the reduced "intensity" score in one year. Applying ETH to AVG-treated fruit improved apple juice "preference" on two of three occasions.

MCP reduced apple juice "intensity" scores in both years, "liking" scores in one year and reduced preferences scores in one of two years. Although not significantly different in both years, the preference for juice from control apples was higher when compared to juice from MCP-treated fruit ( 15 control vs. $10 \mathrm{MCP}$ ).

Bioregulators had little or no influence on the sensory scores for 'Gale Gala' apples either at harvest or after CA storage, except for texture (Table 8). Regardless of the bioregulator used, "overall" acceptance and flavor scores were similar. After CA storage, texture of apples treated with bioregulators was superior to the texture of control apples. 'Gale Gala' apples generally have a strong flavor, particularly when compared to 'Scarletspur Delicious', and it is possible that this stronger flavor could attenuate differences that would be present in apples with less flavor.

Sensory scores for apple juice from 'Gale Gala' apples were influenced by the use of bioregulators (Table 8). Juice from control apples was preferred to juice from apples treated with AVG at harvest or MCP after CA storage. AVG or MCP reduced "intensity" and "liking" scores compared to juice from control apples at harvest and after CA storage, respectively. No difference in sensory scores was present for juice from apples treated with ETH either before or after storage except for the "intensity" score at harvest, which was less than the score for juice from control apples. "Preference" for juice from apples treated with a combination of AVG + ETH compared favorably to juice from control apples at harvest and after CA storage. Juice from AVG + ETH treatments tended to score less for "intensity" and "liking" than juice from control apples. Differences in scores for "intensity" and "liking" tended to be small among bioregulator treatments and possibly of no consequence, but "preference" scores for juice from control apples were definitely superior to the scores for juice from either AVG- or MCP-treated apples. This "preference" for control apple juice was observed for both 'Scarletspur Delicious' and

Table 8. Effects of preharvest aminoethoxyvinylglycine (AVG) and/or ethephon (ETH) with or without postharvest application of 1-methylcyclopropene (MCP) on sensory evaluation of 'Gale Gala' apples and apple juice at harvest and after controlled atmosphere (CA) storage.

\begin{tabular}{|c|c|c|c|c|c|c|}
\hline \multirow[b]{2}{*}{ Bioregulator } & \multicolumn{3}{|c|}{ Apples $^{z}$} & \multicolumn{3}{|c|}{ Juice $^{y}$} \\
\hline & $\begin{array}{l}\text { Overall }^{x} \\
(1-9)\end{array}$ & $\begin{array}{c}\text { Flavor }^{x} \\
(1-9)\end{array}$ & $\begin{array}{l}\text { Texture }^{\mathrm{x}} \\
(1-9)\end{array}$ & $\begin{array}{l}\text { Preference }^{\mathrm{w}} \\
(\mathrm{C} / \mathrm{T})\end{array}$ & $\begin{array}{c}\text { Intensity }^{x} \\
1-9)\end{array}$ & $\begin{array}{l}\text { Liking }^{\mathrm{x}} \\
(1-9)\end{array}$ \\
\hline \multicolumn{7}{|c|}{ Harvest } \\
\hline Control & $7.1 \mathrm{a}^{\mathrm{s}}$ & $7.0 \mathrm{ab}$ & $7.3 \mathrm{a}$ & & $5.5 \mathrm{a}$ & $6.7 \mathrm{a}$ \\
\hline $\mathrm{AVG}^{\mathrm{v}}$ & $7.0 \mathrm{a}$ & $6.8 \mathrm{~b}$ & $7.3 \mathrm{a}$ & $19 / 6^{* *}$ & $5.0 \mathrm{~b}$ & $6.1 \mathrm{~b}$ \\
\hline $\mathrm{ETH}^{\mathrm{u}}$ & $7.3 \mathrm{a}$ & $7.2 \mathrm{a}$ & $7.4 \mathrm{a}$ & $13 / 12$ & $4.9 \mathrm{~b}$ & $6.9 \mathrm{a}$ \\
\hline $\mathrm{AVG}+\mathrm{ETH}$ & $7.3 \mathrm{a}$ & $7.2 \mathrm{a}$ & $7.5 \mathrm{a}$ & $14 / 11$ & $5.3 \mathrm{a}$ & $6.2 \mathrm{~b}$ \\
\hline \multicolumn{7}{|c|}{ After 120 d CA storage } \\
\hline Control & $6.6 \mathrm{a}$ & $6.8 \mathrm{a}$ & $6.0 \mathrm{~b}$ & & $5.1 \mathrm{a}$ & $7.5 \mathrm{a}$ \\
\hline $\mathrm{AVG}^{\mathrm{v}}$ & $6.8 \mathrm{a}$ & $6.5 \mathrm{a}$ & $7.3 \mathrm{a}$ & $11 / 14$ & $5.4 \mathrm{a}$ & $7.4 \mathrm{a}$ \\
\hline $\mathrm{ETH}^{\mathrm{u}}$ & $6.9 \mathrm{a}$ & $6.7 \mathrm{a}$ & $7.2 \mathrm{a}$ & $15 / 10$ & $5.1 \mathrm{a}$ & $7.4 \mathrm{a}$ \\
\hline $\mathrm{AVG}+\mathrm{ETH}$ & --- & --- & --- & $15 / 10$ & $4.6 \mathrm{~b}$ & $7.5 \mathrm{a}$ \\
\hline $\mathrm{MCP}^{\mathrm{t}}$ & $6.6 \mathrm{a}$ & $6.5 \mathrm{a}$ & $7.2 \mathrm{a}$ & $18 / 7^{*}$ & $4.7 \mathrm{~b}$ & $7.1 \mathrm{~b}$ \\
\hline
\end{tabular}

${ }^{2} \mathrm{~N}=200$.

y $=25$.

'Evaluated on a nine-point hedonic scale.

"Number of panelists with preference for control (C) over treatment $(\mathrm{T})$

"AVG applied 4 weeks before anticipated harvest at $125 \mathrm{mg} \cdot \mathrm{L}^{-1}(\mathrm{ppm})$.

"ETH applied 2 weeks before anticipated harvest at $300 \mathrm{mg} \cdot \mathrm{L}^{-1}$.

${ }^{\mathrm{t}} \mathrm{MCP}$ applied at $1.0 \mathrm{mg} \cdot \mathrm{L}^{-1}<12 \mathrm{~h}$ after harvest.

'Means in a column, at harvest or after storage, not followed by a common letter are significantly different $(P \leq$ $0.05)$.
'Gale Gala' apples (Table 7). In both cultivars the use of ETH tended to reduce the adverse influence of AVG on sensory scores.

\section{Conclusions}

Bioregulators can have a major impact on apple fruit and apple juice quality regardless of cultivar. At harvest, AVG retarded starch loss and ethylene concentration in both 'Scarletspur Delicious' and 'Gale Gala' apples and retarded development of cracking in 'Gale Gala' apples. AVG had no influence on color or firmness of 'Scarletspur Delicious' but delayed red color and enhanced firmness in 'Gale Gala' apples regardless of time of harvest. ETH enhanced starch loss and ethylene concentration in both cultivars. ETH enhanced firmness loss and the number of cracks in 'Gale Gala' apples. A combination of AVG + ETH at harvest aided in the reduction of starch loss, ethylene concentration, and firmness loss, particularly in 'Gale Gala' apples.

After both RA and CA storage, AVG continued to attenuate ethylene concentration in both cultivars. Ethylene content of both control and ETH-treated apples was much higher than in apples treated with AVG or a combination of AVG + ETH. Apples treated with AVG + ETH displayed ethylene concentration similar to AVG used alone. Addition of MCP suppressed ethylene concentration in both cultivars regardless of storage condition. AVG alone or in combination with ETH limited loss of firmness in both cultivars. ETH enhanced firmness loss in both cultivars. A major loss of firmness was evident when ETH-treated apples were compared to apples treated with AVG or a combination of AVG + ETH. Application of MCP essentially eliminated firmness loss in both cultivars and maintained exceptional firmness during both RA and CA storage.

Bioregulators can influence sensory acceptance of apples, but sensory quality is strongly influcenced by the cultivar as well as fruit condition. AVG suppressed "overall" acceptance and flavor of 'Scarletspur Delicious' apples and did little for sensory texture, particularly after harvest. Both ETH alone and the combination of AVG + ETH enhanced "overall" acceptance and flavor after harvest but not consistently. After CA storage, AVG reduced "over- 
all" acceptance and flavor but enhanced texture. ETH reduced texture, but not consistently and did little for "overall" acceptance and flavor. MCP reduced "overall" acceptance and flavor one year and enhanced those parameters the other year, but enhanced texture consistently. Sensory acceptance of 'Gale Gala' apples was not influenced by use of bioregulators.

Bioregulators influenced sensory acceptance of apple juice regardless of cultivar. Scores for "preference" were reduced when apple juice was produced from apples treated with AVG, AVG + ETH, or MCP. Flavor scores for apple "intensity" and "liking" were reduced when juice was produced from apples treated with AVG or MCP.

\section{Literature cited}

Andrews P.K. 2001. Gala splitting. Proc. Wash. Tree Fruit Postharvest Conf., 13-14 Mar. 2001, Wenatchee, Wash. p. 1-6.

Beaudry, R. and S. Jayanty. 2003. Improving McIntosh storability: A marriage of ReTain and SmartFresh. Fruit Growers News. I Sept. 2005. <http://www. fruitgrowersnews.com/pages/2003/issue03_09/03_09_mcp_update.html .

Blankenship, S.M. and J.M. Dole. 2003. 1Methylcyclopropene: A review. Postharvest Biol. Technol. 28:1-25.

Boylston, T.D., E.M. Kupferman, J.D. Foss, and C. Buering. 1994. Sensory quality of Gala apples as influenced by controlled and regular atmosphere storage. J. Food Qual. 17:477-494.

Byers, R.E. 1997. Effects of aminoethoxyvinylglycine (AVG) on preharvest drop, maturity, and cracking of several apple cultivars. J. Tree Fruit Prod. 2:77-97.

DeEll, J.R., D.P. Murr, M.D. Proteus, and H.P.V. Rupasinghe. 2002. Influence of temperature and duration of 1-methylcyclopropene (MCP) treatment on apple quality. Postharvest Biol. Technol. 24:349-353

DeLong, J.M., R.K. Prange, and P.A. Harrison. 2004. The influence of 1-methylcyclopropene on 'Cortland' and 'McIntosh' apple quality following long-term storage. HortScience 39:1062-1065.

Drake, S.R., M.A. Drake, S.L. Drake, D.C. Elfving, and T.A. Eisele. 2004. The influence of bioregulators on the instrumental and sensory quality of apples and apple juice. Proc. Inst. Food Technol., 12-16 July 2004, Las Vegas, Nev. 49E-2 (Abstr.).
Drake, M.A., S.R. Drake, D.C. Elfving, and T.A. Eisele. 2002. Influence of bioregulators on apple fruit quality. Proc. Inst. Food Technol., 15-19 June 2002, Anaheim, Calif. 76C-9 (Abstr.).

Drake, S.R., T.A. Eisele, M.A. Drake, D.C. Elfving, S.L. Drake, and D.B. Visser. 2005a. The influence of aminoethoxyvinylglycine and ethephon on objective and sensory quality of 'Delicious' apples and apple juice at harvest and after storage. HortScience 40:2102-2108.

Drake, S.R., T.A. Eisele, D.C. Elfving, M.A. Drake, S.L. Drake, and D.B. Visser. 2005 b. Effects of the bioregulators aminoethoxyvinylglycine and ethephon on brix, carbohydrate, acid, and mineral concentrations in 'Scarletspur Delicious' apple juice. HortScience 40:1421-1424.

Drake, S.R., D.C. Elfving, T.A. Eisele, M.A. Drake, S.L. Drake, and D.B. Visser. 2003. Effects of ethephon and aminoethoxyvinylglycine on the carbohydrate and acids contents of 'Scarletspur Delicious' apples (Malus domestica Borkh.). Proc. Inst. Food Technol., 12-16 July 2003, Chicago. 45F-3 (Abstr.).

Elfving, D.C. and R.A. Cline. 1990. Effects of annually applied growth control techniques on growth and productivity of vigorous 'Northern Spy' /MM.106 apple trees. J. Amer. Soc. Hort. Sci. 115:212-218.

Elfving, D.C., G.A. Lang, and D.B. Visser. 2003. Prohexadione-CA and ethephon reduce shoot growth and increase flowering in young, vigorous sweet cherry trees. HortScience 38:293-298.

Fan, X., S. Blankenship, and J.P. Mattheis. 1999b. MCP inhibits apple fruit ripening. J. Amer. Soc. Hort. Sci. 124:690-695.

Fan, X. and J.P. Mattheis. 1999. Impact of 1-methylcyclopropene and methyl jasmonate on apple volatile production. J. Agr. Food Chem. 47:2847-2853.

Fan, X., J.P. Mattheis, and S. Blankenship. 1999a. Development of superficial scald, coreflush and peel greasiness is reduced by MCP. J. Agr. Food Chem. 47:3063-3068.

Greene, D.W. 2002. Preharvest drop control and maturity of 'Scarletspur Delicious' apples as affected by aminoethoxyvinylglycine (AVG). J. Tree Fruit Prod. 3:1-10.

Greene, D.W., J. Krupa, and J. Clements. 2000. Effects of simulated rain following ReTain application on preharvest drop and fruit quality of McIntosh apples. Fruit Notes 60:57-60.

Hunter, R.S. and R.W. Harold. 1987. The measurement of appearance. 2nd ed. Wiley, New York.
Jordan, R.B., R.J. Seelye, and V.A. McGlone. 2001. A sensory-based alternative to brix/acid ratio. Food Technol. $55: 36-44$.

Larrigaudiere, C., E. Pinto, and M. Vendrell. 1996. Differential effects of ethephon and seniphon on color development of 'Starking Delicious' apple. J. Amer. Soc. Hort. Sci. 121:746-750.

Lawless, H.T. and J. Heymann. 1999. Sensory evaluation of food. Aspen, Gaithersburg, Md.

Layne, D.R., J. Zhengwang, and J.W. Rushing. 2002. The influence of reflective film and ReTain on red skin coloration and maturity of 'Gale Gala' apples. HortTechology 12:640-645.

Lurie, S., C. Pre-Aymard, U. Ravid, O. Larkov, and E. Fallik. 2002. Effects of 1methylcyclopropene on volatile emissions and aroma in cv. Anna apples. J. Agr. Food Chem. 50:4251-4256.

Mattheis, J., X. Fan, and L. Argenta. 2001. Responses of pacific northwest apples to 1-methylcyclopropene (MCP). Wash. Tree Fruit Postharvest Conf., 13-14 Mar. 2001, Wenatchee, Wash. p. 1-3.

Stover, E., J.J. Fargione, C.B. Watkins, and K.A. Iungerman. 2003. Harvest management of Marshall 'McIntosh' apples: Effects of AVG, NAA, ethephon, and summer pruning on preharvest drop and fruit quality. HortScience 38:1093-1099.

Wang, Z. and D.R. Dilley. 2001. Aminoethoxyvinylglycine, combined with ethephon, can enhance red color development without over-ripening apples. HortScience 36:328-331.

Washington Apple Commission. 2002. Red Delicious analysis report. Prepared by TRD Frameworks, Seattle. Washington Apple Commission, Wenatchee.

Washington Apple Maturity Program. 1993. Washington apple maturity handbook. Washington Apple Maturity Program, Wenatchee.

Washington State Legislature. 1990. Washington inspection procedures. Washington Agriculture Code WAC 16-403-142, 15 Jan. 1990. Washington State Legislature, Olympia, Wash.

Watkins, C.B., J.F. Nocker, and B.D. Whitaker. 2000. Responses of early, mid and late season apple cultivars to postharvest application of methylcyclopropene (MCP) under air and controlled atmosphere storage conditions. Postharvest Biol. Technol. 19:17-32.

Williams, M.W. 1980. Retention of fruit firmness and increase in vegetative growth and fruit set of apples with aminoethoxyvinylglycine. HortScience 15:76-77. 